\title{
Gloger's rule in North American Barn Owls
}

\author{
Alexandre Roulin ${ }^{1 *}$ and Christophe Randin ${ }^{2}$ \\ ${ }^{1}$ Department of Ecology and Evolution, University of Lausanne, Lausanne, Switzerland \\ ${ }^{2}$ Landscape Dynamic Unit, Swiss Federal Research Institute WSL, Birmensdorf, Switzerland \\ * Corresponding author: Alexandre.Roulin@unil.ch
}

Submitted July 15, 2014; Accepted October 25, 2014; Published January 7, 2015

\begin{abstract}
Studying the geographic variation of phenotypic traits can provide key information about the potential adaptive function of alternative phenotypes. Gloger's rule posits that animals should be dark- vs. light-colored in warm and humid vs. cold and dry habitats, respectively. The rule is based on the assumption that melanin pigments and/or dark coloration confer selective advantages in warm and humid regions. This rule may not apply, however, if genes for color are acting on other traits conferring fitness benefits in specific climes. Covariation between coloration and climate will therefore depend on the relative importance of coloration or melanin pigments and the genetically correlated physiological and behavioral processes that enable an animal to deal with climatic factors. The Barn Owl (Tyto alba) displays three melanin-based plumage traits, and we tested whether geographic variation in these traits at the scale of the North American continent supported Gloger's rule. An analysis of variation of pheomelanin-based reddish coloration and of the number and size of black feather spots in 1,369 museum skin specimens showed that geographic variation was correlated with ambient temperature and precipitation. Owls were darker red in color and displayed larger but fewer black feather spots in colder regions. Owls also exhibited more and larger black spots in regions where the climate was dry in winter. We propose that the associations between pigmentation and ambient temperature are of opposite sign for reddish coloration and spot size vs. the number of spots because selection exerted by climate (or a correlated variable) is plumage trait-specific or because plumage traits are genetically correlated with different adaptations.
\end{abstract}

Keywords: climate, geographic variation, Gloger's rule, melanin, Tyto alba

\section{Regla de Gloger en América del Norte para la Especie Tyto alba \\ RESUMEN}

El estudio de la variación geográfica de los rasgos fenotípicos puede brindar información clave sobre la potencial función adaptativa de los fenotipos alternativos. La regla de Gloger postula que los animales deberían ser oscuros en ambientes calurosos/húmedos y de colores claros en ambientes fríos/secos. Esto se basa en el supuesto de que los pigmentos de melanina y/o las coloraciones oscuras confieren ventajas adaptativas en las regiones cálidas/húmedas. Sin embrago, esta regla puede no aplicarse si los genes del color están actuando sobre otros rasgos que confieren beneficios en términos de adecuación biológica bajo climas específicos. La covariación entre la coloración y el clima dependerá por ende de la importancia relativa de la coloración/los pigmentos de melanina y de los procesos fisiológicos y comportamentales genéticamente correlacionados para hacer frente a los factores climáticos. Tyto alba presenta tres rasgos del plumaje basados en la melanina. Evaluamos si la variación geográfica a la escala continental de América del Norte apoya la regla de Gloger. Un análisis de la variación de la coloración rojiza basaba en feomelanina y del número y tamaño de las manchas de las plumas negras en 1369 pieles de especímenes de museo mostraron que la variación geográfica estuvo correlacionada con la temperatura y la precipitación del ambiente. Las lechuzas fueron de color rojizo más oscuro y mostraron menos manchas negras pero más grandes en las regiones más frías. Las lechuzas también mostraron más manchas negras y de mayor tamaño en las regiones donde el clima es seco en invierno. Proponemos que las asociaciones entre pigmentación y temperatura del ambiente son de signo opuesto para la coloración rojiza /tamaño de las manchas vs. número de manchas porque la selección ejercida por el clima (o una variable correlacionada) es específica para un rasgo del plumaje o porque los rasgos del plumaje están genéticamente correlacionados con diferentes adaptaciones.

Palabras clave: clima, melanina, regla de Gloger, Tyto alba, variación geográfica. 


\section{INTRODUCTION}

The study of geographic variation in phenotypic traits is key to exploring the adaptive function of alternative phenotypes. At a large geographic scale, such as across a continent, ecological and climatic factors vary greatly among regions, promoting the evolution of specific phenotypes adapted to these specific local conditions (Huey et al. 2000). Local adaptation requires populations to differ genetically (Blanquart et al. 2013), potentially leading to speciation even in the presence of gene flow (Barton 2010). Although studying geographic variation in phenotypic traits has a long history (Wright 1943, Mayr 1956), this approach still remains essential to identifying the potential adaptive function of alternative phenotypes in changing environments (Newton 2003).

As early as 1833, Constantin Gloger noticed that humidity and temperature accounted for geographic variation in bird coloration (Gloger 1833, Caro 2005, Kamilar and Bradley 2011). This led to the development of "Gloger's rule," which states that animals should be darkly colored in warm and humid environments and paler in cold and dry habitats. This rule applies to a large number of animals, including mammals and insects (Mayr 1963, Stoner et al. 2003, Kamilar and Bradley 2011), and in 50 out of 54 (96\%) studies of North American birds, populations were more pigmented in more humid areas (Zink and Remsen 1986). A number of selective processes can explain this pattern (Burtt and Ichida 2004). First, predator-prey interactions may be at the heart of Gloger's rule if dark and pale individuals are cryptic in different habitats (Miller and Miller 1951, Burtt 1981, Zink and Remsen 1986). Second, animals may be darker in wetter habitats because melanin pigments play a role in thermoregulation, or because heavily pigmented feathers repel water better, allowing the body to dry more rapidly (Heppner 1970, Walsberg et al. 1978, Burtt 1981, ClusellaTrullas et al. 2008). Third, melanin pigments may protect the integument against ectoparasites (Ruiz-De-Castañeda et al. 2012) and bacteria (Burtt and Ichida 2004, Goldstein et al. 2004) that thrive in warm and humid habitats (Guernier et al. 2004). Finally, melanin pigments improve hardness of the feathers and hence protect them against abrasion (Bonser and Witter 1993), which might be more pronounced in warm and humid areas.

Recently, it has been proposed that genes that participate in the production of melanin pigments may pleiotropically regulate other phenotypes (Ducrest et al. 2008). These pleiotropic genes may therefore account for the covariation between melanin-based coloration, behaviour, and physiology (Roulin and Ducrest 2011), regardless of whether melanin-based coloration is involved in camouflage or whether melanin pigments participate in thermoregulation or in the protection of the integument against parasites and abrasion. Therefore, not only selection exerted on coloration but also selection exerted on genetically correlated physiological or behavioral traits may account for geographic variation. As a consequence, in contrast to Gloger's rule, we may find that individuals are heavily pigmented in colder and dryer habitats if genes encoding for the production of melanin pleiotropically regulate physiological and/or behavioral processes adapted to such habitats. This mechanism may explain why dark, melanic Pied Flycatchers (Ficedula hypoleuca; Sirkiä et al. 2010) and Tawny Owls (Strix aluco; Karell et al. 2011) are more sensitive to the cold than their pale conspecifics.

Here, we studied geographic variation in three melaninbased plumage traits in North American Barn Owls (Tyto alba pratincola). On museum skin specimens, we counted and measured the size of black eumelanic feather spots, as well as measuring pheomelanin-based coloration, which varies from white to dark red. In European Barn Owls ( $T$. a. alba, T. a. guttata), these three plumage traits are genetically correlated with behavioral and physiological processes (Roulin and Ducrest 2011). For instance, smaller-spotted and redder pheomelanic owls have a higher appetite (Dreiss et al. 2010), and larger-spotted owls are more resistant to parasitism and to various sources of stress that induce a rise in glucocorticoids (Roulin et al. 2000, Almasi et al. 2012). Because the genetics of melanogenesis are very well conserved across vertebrates (Schiöth et al. 2005), plumage traits may be associated with similar phenotypes in North American as in European Barn owls. In this paper, we first describe geographic variation in the three plumage traits and then examine whether rainfall, as a proxy for humidity, and temperature account for geographic variation as predicted by Gloger's rule. According to this rule, we would expect Barn Owls to be darker red and to display more and larger black spots in warm and humid compared with cold and dry regions. However, if plumage traits are genetically correlated with physiological and behavioral traits that are useful for coping with variation in climate or in any correlated environmental variable, plumage traits may evolve through selection exerted by climate on these genetically correlated traits rather than on the plumage traits themselves. Depending on how melanin-based plumage traits are genetically correlated with these physiological and behavioral adaptations, geographic variation in melanin-based traits may or may not follow Gloger's rule.

\section{METHODS}

We obtained data on 1,369 barn owl skins (636 males and 733 females) collected between the years 1844 and 2013 (mean year is 1948) in North America (Appendix A) by 59 natural history museums (Appendix B). Plumage traits 
were assessed on the breast and belly, and mean values over these two body parts were used in the statistical analyses. These methods were reliable, as shown by measuring the same individuals twice (repeatability was 0.90; Roulin 1999, 2004a). A. Roulin compared the degree of reddish coloration against eight chips ranging from -8 for white to -1 for dark red (Roulin et al. 1998); we have previously shown that coloration does not change in museum specimens (Roulin 2003) and that coloration scored by eye is strongly correlated (Pearson's correlation: $r=0.78, n=1,107, P<0.001)$ with reflectance in the range $400-700 \mathrm{~nm}$ as measured with an Ocean Optics S2000 spectrometer (Ocean Optics, Dunedin, Florida, USA) and a PX-2 xenon lamp (Ocean Optics; Dreiss and Roulin 2010). Coloration of skin specimens was not measured with a spectrophotometer because our study started in 1996 when we did not have access to a spectrophotometer. Black spots were counted within a $60 \times 40 \mathrm{~mm}$ frame and their diameter was measured to the nearest $0.1 \mathrm{~mm}$ using calipers. We scored reddish coloration in all 1,369 individuals, and we counted and measured the size of spots in 1,327 and 1,368 individuals, respectively.

The geographic coordinates of the sites where each skin specimen was collected allowed us to extract long-term monthly sums of precipitation and monthly daily mean 2$\mathrm{m}$ ambient temperature from the Worldclim dataset for the period 1950-2000 (http://www.worldclim.org/, Hijmans et al. 2005) at a 30-arc-second spatial resolution. For each individual we had one value per day, for each year we calculated a mean monthly value, and for each month we computed a mean value over the entire period 1950-2000. Therefore, for each skin specimen and each month, we had a mean precipitation level value and a mean ambient temperature value.

We $\log _{10}$-transformed monthly precipitation values to generate a normal distribution for the dataset. To reduce the number of weather variables and to obtain integrative and independent indices of monthly precipitation and ambient temperature, we performed a principal components analysis (PCA; Table 1). We extracted four components (eigenvalues $>1.0$ ) and used them to examine how melanin-based plumage traits were associated with temperature and precipitation.

\section{Statistical Procedures}

All statistical analyses were performed with the software JMP version 9.0.0 (SAS Institute, Cary, North Carolina, USA). In order to compare the extent to which each plumage trait was associated with geographic coordinates and the principal components of weather, we standardized each plumage trait with the formula ([value - mean]/ standard deviation). To test for phenotypic correlations between plumage traits, we performed ANCOVAs. A significant interaction between the factor sex and plumage trait (covariate) on the phenotypically correlated plumage trait (dependent variable) indicates that the magnitude of phenotypic correlation between 2 plumage traits differs between males and females. To compare sexual dimorphism in the 3 plumage traits, we standardized plumage trait values across the 2 sexes. We then ran linear mixed models with standardized plumage traits as dependent variables and individual identity as a random variable, since each individual appears 3 times in the analysis. Sex and trait identity (reddish coloration, number of spots, spot diameter) were 2 factors, and a significant interaction between them indicated that sexual dimorphism differed between traits. To investigate geographic variation in the degree of melanin-based plumage traits, we ran an ANCOVA for each trait including sex as a factor and latitude and longitude plus their interaction as covariates; we added latitude ${ }^{2}$ and longitude ${ }^{2}$ to test for nonlinear relationships. To examine the relationships between temperature, rain, and plumage traits, we introduced the 4 principal components of monthly precipitation and ambient temperature as independent variables in ANCOVAs, including sex as a factor and each plumage trait as a dependent variable in separate analyses. Tests are 2-tailed, and $P$-values lower than 0.05 are considered significant.

\section{RESULTS}

\section{Phenotypic Correlation between Melanin-based Plumage Traits}

The phenotypic correlation between spot diameter and number of spots was significantly stronger in males than in females (Pearson's $r=0.61$ and 0.27, respectively; ANCOVA with spot diameter as dependent variable, sex: $F_{1,1323}=253.13, P<0.001$; number of spots: $F_{1,1323}=$ 308.79, $P<0.001$; interaction: $F_{1,1323}=35.50, P<0.001$ ), as was the phenotypic correlation between pheomelaninbased color and spot diameter $(r=0.41$ and 0.27, respectively; interaction: $\left.F_{1,1364}=6.37, P=0.012\right)$. In contrast, the phenotypic correlation between coloration and number of spots was not significantly different between males and females $(r=0.49$ and 0.36 , respectively; interaction: $\left.F_{1,1323}=1.54, P=0.22\right)$.

\section{Sexual Dimorphism in Melanin-based Plumage Traits} The most strongly sexually dimorphic trait was reddish coloration, followed by spot diameter and number of spots (Table 2). Compared with males, females were on average darker red (females: $-4.23 \pm 0.05$; males: $-6.36 \pm 0.06$ ) and displayed more black spots $(32.0 \pm 0.4$ vs. $27.2 \pm 0.4)$, which were also larger $(2.41 \pm 0.02$ vs. $1.93 \pm 0.02 \mathrm{~mm})$. In a linear mixed model with individual identity as random variable (explaining $41 \%$ of the variation), there was a significant interaction between sex and trait (sex: $F_{1,1370}=$ 
TABLE 1. Principal components analysis of monthly sums of precipitation (log-transformed) and of monthly means of daily mean ambient temperatures in North America. Only the components with eigenvalues larger than 1 are reported.

\begin{tabular}{|c|c|c|c|c|}
\hline & \multicolumn{4}{|c|}{ Principal components of weather } \\
\hline & $1^{\text {st }}$ & $2^{\text {nd }}$ & $3^{\text {rd }}$ & $4^{\text {th }}$ \\
\hline Eigenvalues & 10.87 & 5.98 & 4.77 & 1.46 \\
\hline$\%$ variance & 45.31 & 24.91 & 19.87 & 6.09 \\
\hline \multicolumn{5}{|l|}{ Eigenvectors } \\
\hline \multicolumn{5}{|l|}{ Precipitation } \\
\hline January & -0.117 & 0.161 & 0.370 & -0.004 \\
\hline February & -0.108 & 0.190 & 0.354 & 0.142 \\
\hline March & -0.145 & 0.216 & 0.274 & 0.209 \\
\hline April & -0.111 & 0.323 & 0.127 & 0.154 \\
\hline May & 0.001 & 0.369 & -0.126 & -0.014 \\
\hline June & 0.054 & 0.334 & -0.216 & -0.160 \\
\hline July & 0.087 & 0.278 & -0.283 & -0.083 \\
\hline August & 0.092 & 0.283 & -0.270 & -0.079 \\
\hline September & 0.112 & 0.326 & -0.189 & -0.140 \\
\hline October & 0.027 & 0.376 & -0.013 & -0.211 \\
\hline November & -0.132 & 0.267 & 0.269 & -0.002 \\
\hline December & -0.143 & 0.207 & 0.306 & 0.050 \\
\hline \multicolumn{5}{|l|}{ Temperature } \\
\hline January & 0.246 & -0.042 & 0.216 & -0.260 \\
\hline February & 0.250 & -0.057 & 0.206 & -0.241 \\
\hline March & 0.276 & -0.011 & 0.154 & -0.176 \\
\hline April & 0.295 & 0.032 & 0.075 & -0.062 \\
\hline May & 0.296 & 0.063 & 0.005 & 0.091 \\
\hline June & 0.273 & 0.067 & -0.062 & 0.300 \\
\hline July & 0.240 & 0.042 & -0.067 & 0.477 \\
\hline August & 0.255 & 0.046 & -0.021 & 0.428 \\
\hline September & 0.283 & 0.034 & 0.078 & 0.242 \\
\hline October & 0.285 & 0.010 & 0.146 & 0.015 \\
\hline November & 0.271 & 0.020 & 0.179 & -0.146 \\
\hline December & 0.255 & -0.009 & 0.204 & -0.239 \\
\hline
\end{tabular}

481.70, $P<0.001$; trait: $F_{1,2706}=0.67, P=0.51$; interaction: $\left.F_{1,2706}=93.43, P<0.001\right)$, indicating that sexual dimorphism differed between plumage traits. By performing similar analyses with pairs of plumage traits (number of spots $\times$ reddish coloration, number of spots $\times$ spot diameter, spot diameter $\times$ reddish coloration), we found that the degree of sexual dimorphism differed significantly among all traits $(P$-values for all three interactions between sex and trait were $<0.001$; Figure 1$)$.

\section{Geographic Variation in Melanin-based Plumage Traits}

In the northern parts of the North American continent, Barn Owls were darker red and displayed more and larger black spots than in the southern parts of the continent (Table 2, Figures 2 and 3). Owls were darker red and displayed fewer spots on the West Coast than on the East Coast (Table 2, Figures 2 and 3). These relationships were not linear (Table 2). With respect to latitude, owls were paler red and displayed fewer and smaller black spots in

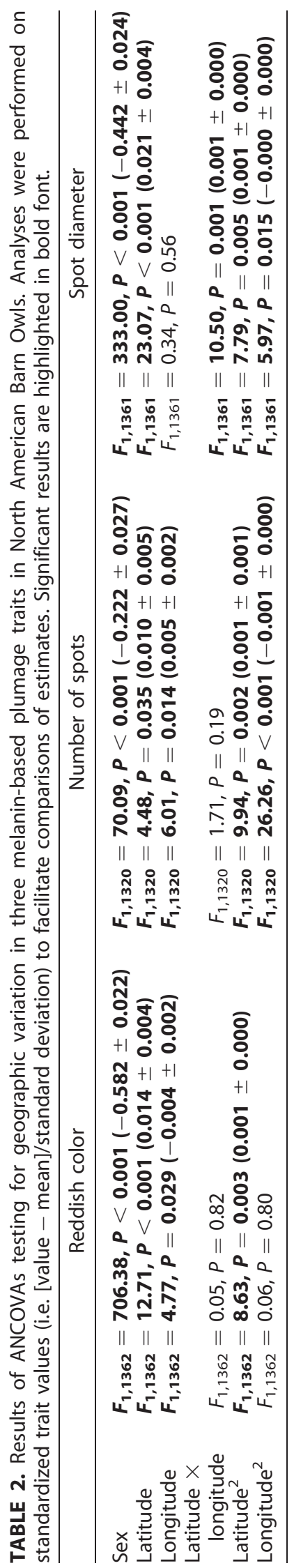




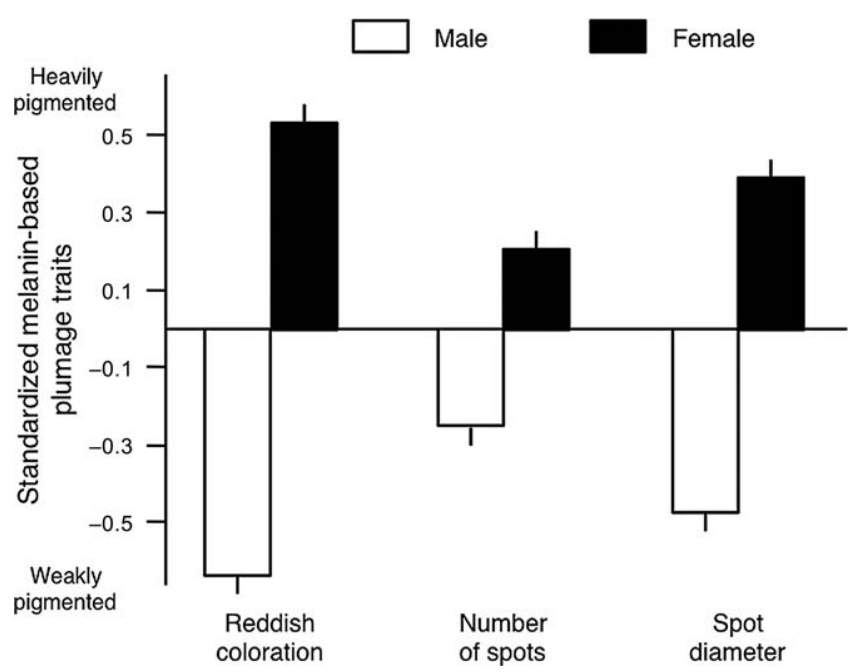

FIGURE 1. Mean standardized plumage trait values in male and female North American Barn Owls. This figure shows that sexual dimorphism is most pronounced in pheomelanin-based reddish coloration, followed by spot diameter and then number of black spots.

the center of the continent than in the southern and northern parts (Figure 3). With respect to longitude, owls exhibited more and larger black spots in the center of the continent than on the West and East coasts (Figure 3).

\section{Climate}

Reddish coloration was significantly negatively related to the first principal component of weather (Figure 4A), and there was a tendency for a negative association with the fourth principal component (Tables 1 and 3). This indicates that owls were darker red in colder regions, particularly in summer.

The number of black spots was significantly positively associated with the first principal component of weather and was negatively associated with the third component (Table 3, Figure 4). This means that owls displayed more black spots in regions where it was warmer and where it rained less in winter but more in summer.

Spot size was negatively associated with the first and third principal components of weather (Table 3, Figure 4). This indicates that owls displayed larger black spots in regions where it was colder, particularly in winter, and where it rained less in winter but more in summer.

For all 3 plumage traits, interactions between sex and the 4 principal components of weather were not significant $(P$-values $>0.06)$, and hence are not reported in the final models (Table 3). Furthermore, when we modeled all 3 plumage traits together rather than separately, we obtained qualitatively similar results (not shown). This indicates that the relationship between climate and a given plumage trait was not confounded by the other phenotypically correlated plumage traits.

\section{DISCUSSION}

In North American Barn Owls, the three melanin-based plumage traits were associated with ambient temperature and precipitation. Owls were darker red and displayed larger but fewer black spots in colder regions. Furthermore, owls tended to display fewer and larger black spots in regions where the climate was rather cold (Figure 4A) and dry in winter but wet in summer. Two sources of noise may have prevented us from detecting stronger relationships, or may have hidden existing relationships. First, because skin specimens were collected between 1844 and 2013, whereas climatic values were available for the period 1950-2000, for each specimen we assigned the mean climatic value for the period 1950-2000 instead of the actual value for the year when an individual was collected. Second, in northern parts of the North American continent, Barn Owls appear to be (partially) migratory (Stewart 1952, Bolen 1978, Bunn et al. 1982). Unfortunately, we cannot evaluate the impact of these two drawbacks on our analyses, and hence further work is required on geographic variation in North American Barn Owls.

\section{Sexual Dimorphism and Phenotypic Correlations}

As in Europe, sexual dimorphism of Barn Owls in North America was more pronounced in pheomelanin-based coloration than in the size of eumelanic spots, which was itself more pronounced than sexual dimorphism in the number of eumelanic spots (A. Roulin personal observation). A major issue is whether sexual dimorphism is related to the degree of sex-specific selection, i.e. whether selection on females to be more melanistic than males is much more pronounced with respect to pheomelaninbased coloration than spot size and spot number. Because none of the interactions between sex and the principal components of weather were significant (Table 3), it seems that climate (or a correlated variable) has similar selective impact on plumage for males as for females. As in Europe, phenotypic correlations between plumage traits were stronger in males than in females on the northern American continent (Roulin 2004a). These results suggest that the quantitative and molecular genetics of melaninbased plumage traits are globally similar in European and North American Barn owls.

\section{Climate and Melanin-based Plumage Traits}

A number of studies have demonstrated a link between melanin-based plumage traits and survival along a gradient of temperature. In two species of owl, Eurasian Scops-Owl (Otus scops) and Tawny Owl, the dark reddish morph increased in frequency during the last century in Europe, apparently as a consequence of climate warming (Galeotti et al. 2009, Karell et al. 2011). These observations suggest that less melanistic individuals survive better in cold 
A Annual mean air temperature

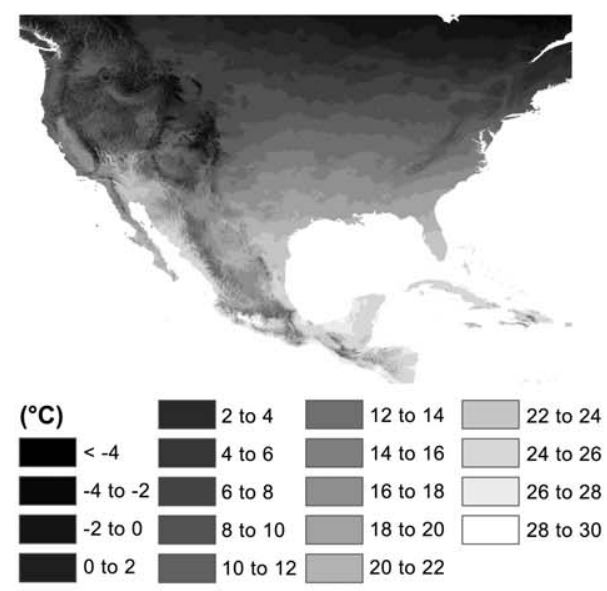

\section{B Annual sum of precipitation}

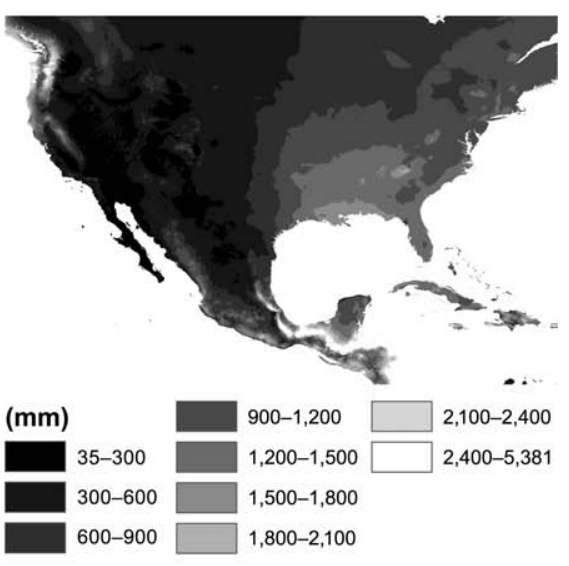

E Spot diameter based color

D Number of black spots

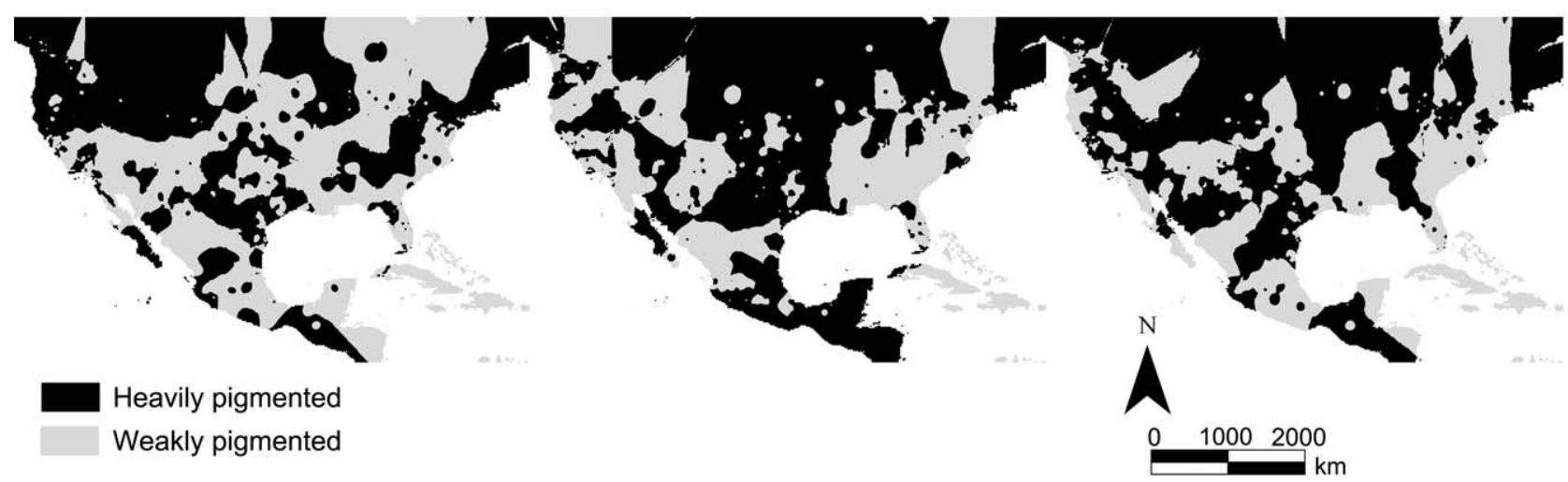

FIGURE 2. Long-term annual mean 2-m ambient temperature (A) and annual sum of precipitation (B) from the Worldclim dataset (http://www.worldclim.org/) for the period 1950-2000 at a 30-arc-second spatial resolution, and spatial interpolations of standardized values corrected for sex of the 3 melanin-based plumage traits of North American Barn Owls: reddish pheomelaninbased color (C), and number (D) and diameter of black feather spots (E). Standardized values of the 3 plumage traits corrected for sex have been classified into weakly and heavily pigmented using the natural breaks algorithm for a better display.

regions and more melanistic individuals in warm regions. This interpretation is consistent with a comparative study of owls at the worldwide scale. In the northern hemisphere, owls of the genus Strix, Glaucidium, Megascops, and Otus are indeed paler poleward and darker red near the equator, as predicted by Gloger's rule (Roulin et al. 2011). Color-specific performance under different ambient temperatures has also been found in Pied Flycatchers: in cold ambient temperatures for rearing, nestlings had higher survival when their father was pale rather than dark, whereas in warm temperatures the opposite tendency was detected (Sirkiä et al. 2010). Thus, fitness differences between dark and pale flycatchers appear to be stronger in cold than warm ambient temperatures. It remains unclear whether these results are due to selection being directly exerted on plumage traits or because of genetically correlated traits. For instance, genes of the melanocortin system not only regulate melanogenesis, but also other phenotypes such as energy homeostasis and thermoregulation (Ducrest et al. 2008).

Barn Owls were darker red (and displayed larger black spots) in the northern parts of the American continent (Figure 3), in contrast to the pattern observed among owl species (Roulin et al. 2011). This may suggest that selective agents exerted on reddish coloration in the Barn Owl are not the same as those exerted on other owl species. If cold ambient temperatures may indeed select darker reddish over lighter reddish Barn Owls (Figure 4A), predator-prey interactions may also play a role. In both Switzerland and Israel, dark reddish owls are mainly found in fields, and white owls close to forests, something that could explain why dark and pale reddish Barn Owls have a different diet in these two countries (Roulin 2004b, Charter et al. 2012, Dreiss et al. 2012). Because Barn Owls in the USA 


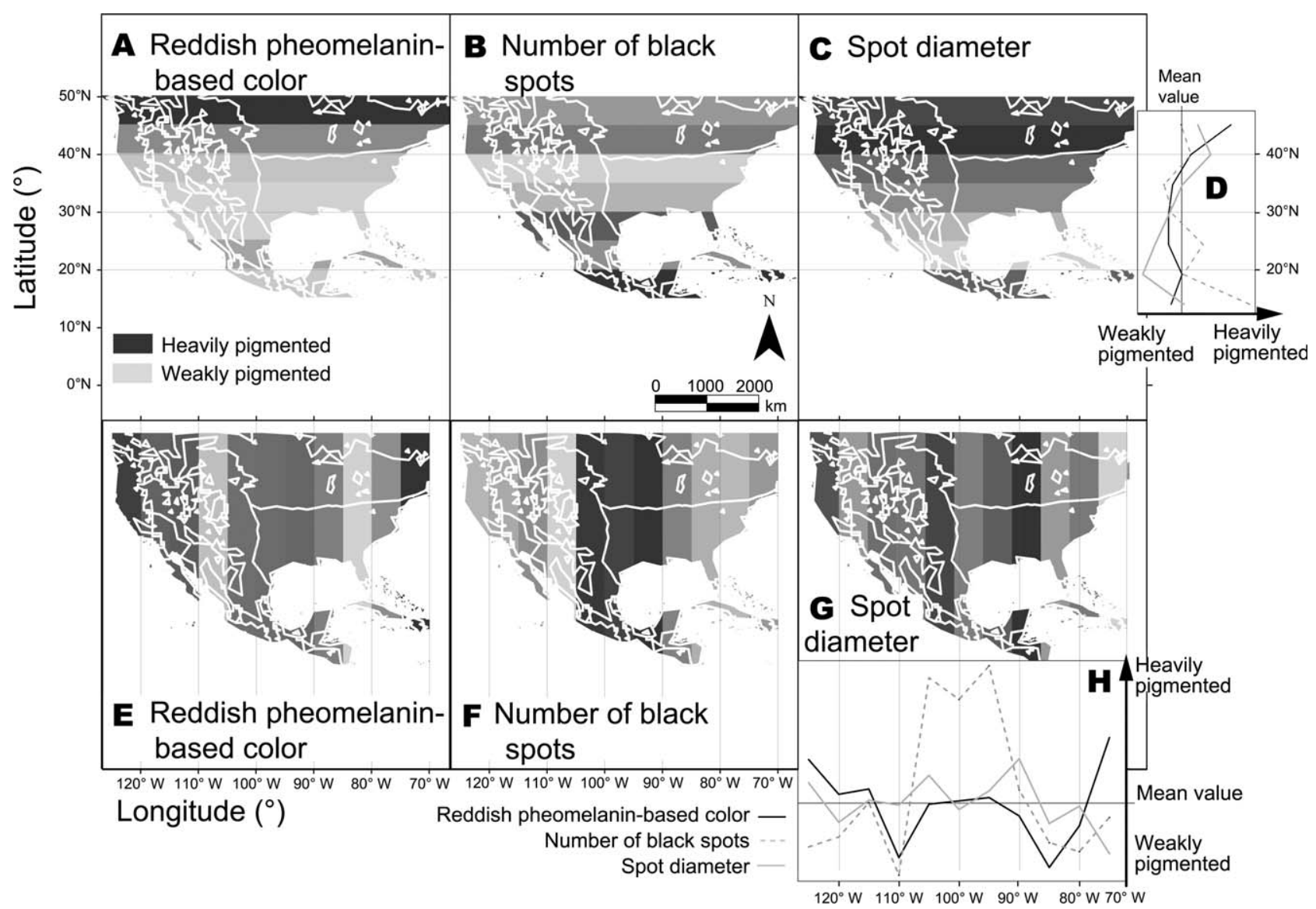

FIGURE 3. Standardized values ([value - mean]/standard deviation) of the 3 melanin-based plumage traits in North American Barn Owls projected into the geographic space and modeled in bins of $5^{\circ}$ as a function of latitude $(\mathbf{A}-\mathbf{C})$ and longitude (E-G) according to the relationships between the three traits and latitude (D) and longitude (H). Modeled values of latitude and longitude have been calculated using a mowing window of $5^{\circ}$ to calculate the mean values of each plumage trait in each $5^{\circ}$ latitudinal or $5^{\circ}$ longitudinal bin. The 3 plumage traits were initially standardized across the 2 sexes to allow comparison, and variation explained by sex was removed.

consume more shrews and fewer rodents in regions where it rains more (Clark and Bunck 1991), it is possible that the association between reddish coloration and climate may be driven by predator-prey relationships. If the predatorprey relationship is the main selective agent in the Barn Owl, whereas climate exerts the most selective pressure in other owls, this could explain why cline variation in the degree of pheomelanin-based coloration in the Barn Owl does not follow the general pattern observed in other owls.

Interestingly, we detected the opposite relationship between the first principal component of weather and the number of black spots vs. reddish coloration and spot size (Figure 4A). In colder regions, Barn Owls displayed fewer spots but larger spots and a darker reddish plumage, which is particularly remarkable given that the number of spots was positively correlated with reddish coloration and spot size. These phenotypic correlations imply that selection toward displaying fewer spots in colder regions must be particularly strong, in order to counteract indirect selection due to dark reddish and large-spotted owls being favored in cold climates. A potential scenario to explain this finding is that genes that generate variation in the number of spots pleiotropically regulate processes associated with thermoregulation other than plumage traits, and hence selection on these correlated thermoregulatory traits constrains selection on the number of spots due to Gloger's rule. Indeed, unpublished results for European Barn Owls have shown that body temperature and thermoregulation are associated with the number of black spots, but not with reddish coloration or spot size. Whatever the reason for spot size and spot number not being similarly correlated with climate, our results suggest that the adaptive function of these two plumage traits is not the same.

\section{Conclusion and Perspectives}

In North American Barn Owls, geographic variation in melanin-based plumage traits is consistent with Gloger's 

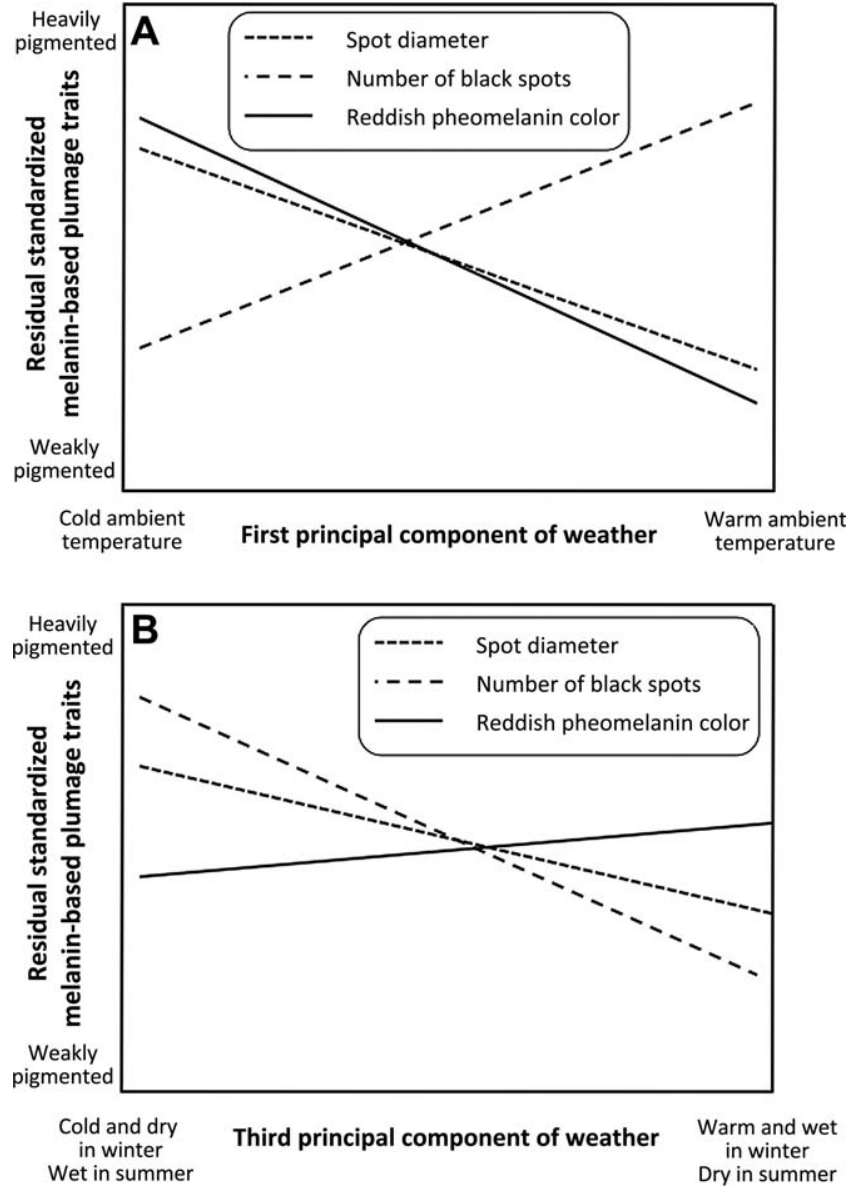

FIGURE 4. Melanin-based coloration in relation to indices of weather in North American Barn Owls. Regression lines are shown for the relationships between plumage traits (initially corrected for sex) and the first (A) and third (B) principal components of weather (Table 1$)$.

rule with respect to the number of black spots, but not with regard to pheomelanin-based coloration and spot size. Patterns of geographic variation may not always follow Gloger's rule because selective factors other than climate may act on melanin-based plumage traits, or because genes for plumage traits may also regulate physiological or behavioral processes related to thermoregulation other than plumage characteristics. Experiments are now required to measure how differently colored Barn Owls cope with various temperatures. For instance, Mosher and Henny (1976) measured oxygen consumption in differently colored Eastern Screech-Owls (Megascops asio) at different ambient temperatures. A similar design could be used with hatchlings swapped between nests, in order to measure the performance of individuals raised by foster parents in relation to plumage traits assessed in the nestlings themselves and in their

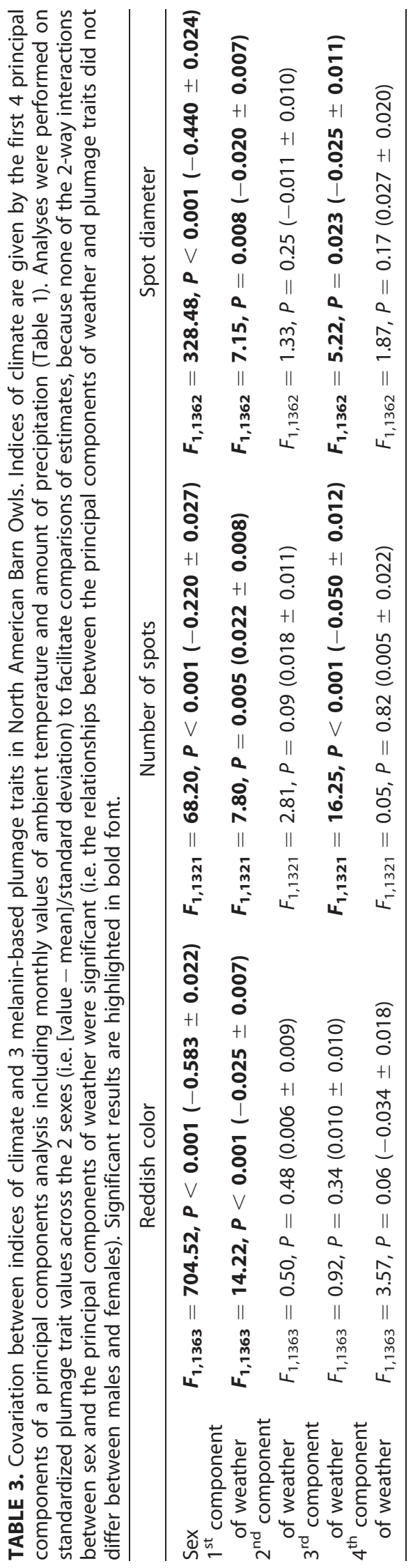


biological and foster parents. In this way, it would be possible to disentangle genetic from environmental effects on the relationship between plumage traits and the ability to cope with cold and warm temperatures. A relationship with the coloration measured in the foster parents would indicate that nestlings raised by differently colored parents experienced different rearing conditions that altered their performance under different temperatures. A relationship with the coloration measured in the biological parents would indicate that plumage traits are genetically correlated with physiological or behavioral process related to thermoregulation. Our study should therefore be considered as just a first attempt to identify the adaptive value of melanin-based plumage traits in North American Barn Owls.

\section{ACKNOWLEDGMENTS}

We warmly thank all curators who opened their museums to us to measure Barn Owl skins for their hospitality. We hope that this study helps to demonstrate how important museum collections are to tackling scientific questions. We are grateful to Reto Burri, Sylvain Antoniazza, and two anonymous reviewers for useful comments on a previous version of the manuscript.

Funding statement. This study was financed by the Swiss National Science Foundation, the American Natural History Museum in New York, the Swiss Academy of Sciences, the Basler Stiftung für biologische Forschung, and the "Fondation $\mathrm{du} 450^{\text {ème }}$ anniversaire" and "Fondation Agassiz" of the University of Lausanne. No funders had any input into the manuscript content, nor required approval of the manuscript prior to publication.

\section{LITERATURE CITED}

Almasi, B., A. Roulin, F. Korner-Nievergelt, S. Jenni-Eiermann, and L. Jenni (2012). Coloration signals the ability to cope with elevated stress hormones: Effects of corticosterone on growth of Barn Owls is associated with melanism. Journal of Evolutionary Biology 25:1189-1199.

Barton, N. H. (2010). What role does natural selection play in speciation? Philosophical Transactions of the Royal Society of London, Series B 365:1825-1840.

Blanquart, F., O. Kaltz, S. L. Nuismer, and S. Gandon (2013). A practical guide to measuring local adaptation. Ecology Letters 16:1195-1205.

Bolen, E. G. (1978). Long-distance displacement of two southern Barn Owls. Bird Banding 49:78-79.

Bonser, R. H. C., and M. S. Witter (1993). Indentation hardness of the bill keratin of the European Starling, Sturnus vulgaris. The Condor 95:736-738.

Bunn, D. S., A. B. Warburton, and R. D. S. Wilson (1982). The Barn Owl. Poyser Monographs, volume 25. T \& AD Poyser, London.

Burtt, E. H. (1981). The adaptiveness of animal colors. Bioscience $31: 723-729$.
Burtt, E. H., and J. M. Ichida (2004). Gloger's rule, featherdegrading bacteria, and color variation among Song Sparrows. The Condor 106:681-686.

Caro, T. (2005). The adaptive significance of coloration in mammals. BioScience 55:125-136.

Charter, M., O. Peleg, Y. Leshem, and A. Roulin (2012). Similar patterns of local Barn Owl adaptation in the Middle East and Europe with respect to melanic coloration. Biological Journal of the Linnean Society 106:447-454.

Clark, D. R., and C. M. Bunck (1991). Trends in North American small mammals found in Common Barn-Owl (Tyto alba) dietary studies. Canadian Journal of Zoology 69:3093-3102.

Clusella-Trullas, S., J. S. Terblanche, T. M. Blackburn, and S. L. Chown (2008). Testing the thermal melanism hypothesis: $A$ macrophysiological approach. Functional Ecology 22:232238.

Dreiss, A. N., and A. Roulin (2010). Age-related change in melanin-based coloration: Females that become more female-like and males more male-like with age perform better in Barn Owls (Tyto alba). Biological Journal of the Linnean Society 101:689-704.

Dreiss, A. N., S. Antoniazza, R. Burri, L. Fumagalli, C. Sonnay, C. Frey, J. Goudet, and A. Roulin (2012). Local adaptation and matching habitat choice in female Barn Owls with respect to melanic coloration. Journal of Evolutionary Biology 25:103114.

Dreiss, A. N., I. Henry, C. Ruppli, B. Almasi, and A. Roulin (2010). Darker eumelanic Barn Owls better withstand food depletion through resistance to food deprivation and lower appetite. Oecologia 164:65-71.

Ducrest, A.-L., L. Keller, and A. Roulin (2008). Pleiotropy in the melanocortin system, coloration and behavioural syndromes. Trends in Ecology \& Evolution 23:502-510.

Galeotti, P., D. Rubolini, R. Sacchi, and M. Fasola (2009). Global changes and animal phenotypic responses: Melanin-based plumage redness of Scops Owls increase with temperature and rainfall during the last century. Biology Letters 5:532-534.

Gloger, C. L. (1833). Das Abändern der Vögel durch Einfluss des Klima's. August Schulz und Comp., Breslau, Germany.

Goldstein, G., K. R. Flory, B. A. Browne, S. Majid, J. M. Ichida, and E. H. Burtt (2004). Bacterial degradation of black and white feathers. The Auk 121:656-659.

Guernier, V., M. E. Hochberg, and J.-F. Guégan (2004). Ecology drives the worldwide distribution of human diseases. PLOS Biology 2:e141. doi:10.1371/journal.pbio.0020141.

Heppner, F. (1970). The metabolic significance of differential absorption of radiant energy by black and white birds. The Condor 72:50-59.

Hijmans, R. J., S. E. Cameron, J. L. Parra, P. G. Jones, and A. Jarvis (2005). Very high resolution interpolated climate surfaces for global land areas. International Journal of Climatology 25: 1965-1978.

Huey, R. B., G. W. Gilchrist, M. L. Carlson, D. Berrigan, and L. Serra (2000). Rapid evolution of a geographic cline in size in an introduced fly. Science 287:308-309.

Kamilar, J. M., and B. J. Bradley (2011). Interspecific variation in primate coat colour supports Gloger's rule. Journal of Biogeography 38:2270-2277.

Karell, P., K. Ahola, T. Karstinen, J. Valkama, and J. E. Brommer (2011). Climate change drives microevolution in a wild bird. 
Nature Communications 2:article 208. doi:10.1038/ ncomms1213

Mayr, E. (1956). Geographical character gradients and climatic adaptation. Evolution 10:105-108.

Mayr, E. (1963). Animal Species and Evolution. Harvard University Press, Cambridge, MA, USA.

Miller, A. H., and L. Miller (1951). Geographic variation of the Screech Owls of the deserts of western North America. The Condor 53:161-177.

Mosher, J. A., and C. J. Henny (1976). Thermal adaptiveness of plumage color in Screech Owls. The Auk 93:614-619.

Newton, I. (2003). The Speciation and Biogeography of Birds. Academic Press, Amsterdam.

Roulin, A. (1999). Nonrandom pairing by male Barn Owls Tyto alba with respect to a female plumage trait. Behavioral Ecology 10:688-695.

Roulin, A. (2003). Geographic variation in sexually selected traits: A role for direct selection or genetic correlation? Journal of Avian Biology 34:251-258.

Roulin, A. (2004a). Proximate basis of the covariation between a melanin-based female ornament and offspring quality. Oecologia 140:668-675.

Roulin, A. (2004b). Covariation between plumage colour polymorphism and diet in the Barn Owl Tyto alba. Ibis 146: 509-517.

Roulin, A., and A.-L. Ducrest (2011). Association between melanism, physiology and behaviour: A role for the melanocortin system. European Journal of Pharmacology 660:226-233.

Roulin, A., R. Burri, and S. Antoniazza (2011). Owl melanin-based plumage redness is more frequent near than away from the equator: Implications on the effect of climate change on biodiversity. Biological Journal of the Linnean Society 102: 573-582.

Roulin, A., M. Kölliker, and H. Richner (2000). Barn Owl (Tyto alba) siblings vocally negotiate resources. Proceedings of the Royal Society of London, Series B 267:459-463.

Ruiz-De-Castañeda, R., E. H. Burtt, S. González-Braojos, and J. Moreno (2012). Bacterial degradability of an intrafeather unmelanized ornament: A role of feather-degrading bacteria in sexual selection? Biological Journal of the Linnean Society 105:409-419.

Schiöth, H. B., T. Haitina, M. K. Ling, A. Ringholm, R. Fredriksson, M. Cerda-Reverter, and J. Klovins (2005). Evolutionary conservation of the structural, pharmacological, and genomic characteristics of the melanocortin receptor subtypes. Peptides 26:1886-1900.

Sirkiä, P. M., M. Virolainen, and T. Laaksonen (2010). Melanin coloration has temperature-dependent effect on breeding performance that may maintain phenotypic variation in a passerine bird. Journal of Evolutionary Biology 23:2385-2396.

Stewart, P. A. (1952). Dispersal, breeding behaviour, and longevity of banded Barn Owls in North America. The Auk 69:227-245.

Stoner, C. J., O. R. P. Bininda-Emonds, and T. Caro (2003). The adaptive significance of coloration in lagomorphs. Biological Journal of the Linnean Society 79:309-328.

Walsberg, G. E., G. S. Campbell, and J. R. King (1978). Animal coat color and radiative heat gain: A re-evaluation. Journal of Comparative Physiology 126:211-222.

Wright, S. (1943) Isolation by distance. Genetics 28:114-138.

Zink, R. M., and J. V. Remsen (1986). Evolutionary processes and patterns of geographic variation in birds. Current Ornithology 4:1-69. 
Appendix A. Locations where Barn Owl skins considered in the present study were collected in North America by Natural History Museums.

\begin{tabular}{|c|c|c|c|}
\hline Country (state or province) & Male Barn Owls & Female Barn Owls & Total \\
\hline Canada (British Columbia) & 1 & 4 & 5 \\
\hline Canada (Ontario) & 7 & 8 & 15 \\
\hline Canada (Québec) & 1 & 2 & 3 \\
\hline Mexico & 41 & 47 & 88 \\
\hline USA (Alabama) & 4 & 0 & 4 \\
\hline USA (Arizona) & 31 & 21 & 52 \\
\hline USA (Arkansas) & 1 & 1 & 2 \\
\hline USA (California) & 170 & 156 & 326 \\
\hline USA (Colorado) & 11 & 13 & 24 \\
\hline USA (Connecticut) & 4 & 3 & 7 \\
\hline USA (Delaware) & 1 & 4 & 5 \\
\hline USA (District of Columbia) & 10 & 5 & 15 \\
\hline USA (Florida) & 30 & 56 & 86 \\
\hline USA (Georgia) & 2 & 0 & 2 \\
\hline USA (Idaho) & 3 & 5 & 8 \\
\hline USA (Illinois) & 6 & 12 & 18 \\
\hline USA (Indiana) & 7 & 2 & 9 \\
\hline USA (lowa) & 1 & 4 & 5 \\
\hline USA (Kansas) & 9 & 10 & 19 \\
\hline USA (Louisiana) & 11 & 8 & 19 \\
\hline USA (Maryland) & 15 & 6 & 21 \\
\hline USA (Massachusetts) & 1 & 3 & 4 \\
\hline USA (Michigan) & 8 & 16 & 24 \\
\hline USA (Minnesota) & 2 & 3 & 5 \\
\hline USA (Mississippi) & 0 & 2 & 2 \\
\hline USA (Missouri) & 1 & 1 & 2 \\
\hline USA (Nebraska) & 4 & 2 & 6 \\
\hline USA (Nevada) & 3 & 2 & 5 \\
\hline USA (New Jersey) & 8 & 14 & 22 \\
\hline USA (New Mexico) & 25 & 34 & 59 \\
\hline USA (New York) & 11 & 11 & 22 \\
\hline USA (North Carolina) & 7 & 7 & 14 \\
\hline USA (Ohio) & 30 & 35 & 65 \\
\hline USA (Oklahoma) & 7 & 8 & 15 \\
\hline USA (Oregon) & 13 & 23 & 36 \\
\hline USA (Pennsylvania) & 10 & 18 & 28 \\
\hline USA (Rhode Island) & 3 & 2 & 5 \\
\hline USA (South Carolina) & 1 & 3 & 4 \\
\hline USA (Tennessee) & 1 & 0 & 1 \\
\hline USA (Texas) & 69 & 90 & 159 \\
\hline USA (Utah) & 8 & 5 & 13 \\
\hline USA (Virginia) & 3 & 6 & 9 \\
\hline USA (Washington) & 53 & 75 & 128 \\
\hline USA (West Virginia) & 0 & 1 & 1 \\
\hline USA (Wisconsin) & 2 & 5 & 7 \\
\hline Total & 636 & 733 & 1369 \\
\hline
\end{tabular}


Appendix B. List of museums where American Barn Owls (Tyto alba pratincola) were measured for the present study.

\begin{tabular}{|c|c|c|c|}
\hline Country (state or province) & City & Museum & No. of skins \\
\hline Canada (Ontario) & Ottawa & Musée Canadien de la Nature & 7 \\
\hline Canada (Ontario) & Toronto & Royal Ontario Museum, Department of Natural History & 31 \\
\hline France & Paris & Musée national d'Histoire naturelle & 2 \\
\hline Germany & Bonn & Alexander Koenig Research Museum & 1 \\
\hline The Netherlands & Leiden & National Museum of Natural History & 5 \\
\hline Switzerland & Neuchâtel & Musée d'histoire naturelle & 1 \\
\hline UK & Cambridge & Cambridge University Museum of Zoology & 2 \\
\hline UK & Edinburgh & National Museums of Scotland, Royal Museum & 1 \\
\hline UK & Liverpool & World Museum Liverpool & 1 \\
\hline UK & Tring & Natural History Museum at Tring & 13 \\
\hline USA (Arizona) & Flagstaff & Museum of Northern Arizona & 5 \\
\hline USA (Arizona) & Tucson & University of Arizona Museum of Natural History & 14 \\
\hline USA (California) & Berkeley & The Museum of Vertebrate Zoology & 85 \\
\hline USA (California) & Camarillo & Western Foundation of Vertebrate Zoology & 43 \\
\hline USA (California) & Los Angeles & The Moore Laboratory of Zoology & 10 \\
\hline USA (California) & Los Angeles & UCLA-Dickey Bird and Mammal Collections & 10 \\
\hline USA (California) & Los Angeles & Natural History Museum of Los Angeles County & 19 \\
\hline USA (California) & Redlands & San Bernardino County Museum & 10 \\
\hline USA (California) & San Diego & San Diego Natural History Museum & 32 \\
\hline USA (California) & San Francisco & The California Academy of Sciences & 55 \\
\hline USA (California) & Santa Barbara & Santa Barbara Museum of Natural History & 7 \\
\hline USA (Colorado) & Denver & Denver Museum of Nature \& Science & 26 \\
\hline USA (Connecticut) & New Haven & Peabody Museum of Natural History at Yale University & 12 \\
\hline USA (Delaware) & Wilmington & Delaware Museum of Natural History & 15 \\
\hline USA (District of Columbia) & Washington DC & Smithsonian Institution, Natural Museum of Natural History & 92 \\
\hline USA (Florida) & Gainesville & Florida Museum of Natural History, University of Florida & 31 \\
\hline USA (Hawaii) & Honolulu & Bishop Museum & 1 \\
\hline USA (Illinois) & Chicago & $\begin{array}{l}\text { The Chicago Academy of Sciences and its Peggy Notebaert } \\
\text { Nature Museum }\end{array}$ & 13 \\
\hline USA (Illinois) & Chicago & The Field Museum of Natural History & 74 \\
\hline USA (Kansas) & Lawrence & Natural History Museum \& Biodiversity Research Center & 31 \\
\hline USA (Louisiana) & Baton Rouge & Louisiana Museum of Natural Science & 38 \\
\hline USA (Massachusetts) & Cambridge & Harvard Museum of Natural History & 69 \\
\hline USA (Michigan) & Ann Arbor & University of Michigan, Museum of Zoology & 51 \\
\hline USA (Michigan) & East Lansing & Michigan State University Museum & 5 \\
\hline USA (Minnesota) & Minneapolis & The University of Minnesota, Bell Museum of Natural History & 8 \\
\hline USA (Montana) & Missoula & Philip L. Wright Zoological Museum & 2 \\
\hline USA (Nebraska) & Lincoln & University of Nebraska State Museum & 7 \\
\hline USA (New Mexico) & Albuquerque & Museum of Southwestern Biology & 48 \\
\hline USA (New Mexico) & Las Cruces & The Vertebrate Museum, New Mexico State University & 7 \\
\hline USA (New York) & Buffalo & Buffalo Museum of Science & 5 \\
\hline USA (New York) & Cornell & Cornell University & 22 \\
\hline USA (New York) & New York & American Museum of Natural History & 73 \\
\hline USA (Ohio) & Cleveland & Cleveland Museum of Natural History & 36 \\
\hline USA (Ohio) & Columbus & The Ohio State University & 26 \\
\hline USA (Oklahoma) & Norman & Sam Noble Oklahoma Museum of Natural History & 12 \\
\hline USA (Pennsylvania) & Philadelphia & Academy of Natural Sciences & 24 \\
\hline USA (Pennsylvania) & Pittsburgh & Carnegie Museum of Natural History & 39 \\
\hline USA (Texas) & Alpine & Sul Ross State University & 2 \\
\hline USA (Texas) & College Station & Texas A\&M University College Station & 41 \\
\hline USA (Texas) & Dallas & Museum of Nature and Science & 8 \\
\hline USA (Texas) & El Paso & Centennial Museum, University of Texas & 6 \\
\hline USA (Texas) & Lubbock & Texas Technology University & 13 \\
\hline USA (Texas) & San Angelo & Angelo State University, Department of Biology & 8 \\
\hline USA (Utah) & Provo & Young University & 11 \\
\hline USA (Utah) & Salt Lake City & Utah Museum of Natural History & 3 \\
\hline USA (Washington) & Pullman & Washington State University, Charles R. Conner Museum & 54 \\
\hline USA (Washington) & Seattle & Burke Museum & 44 \\
\hline USA (Washington) & Tacoma & Slater Museum of Natural History & 49 \\
\hline USA (Wisconsin) & Madison & University of Wisconsin, Zoological Museum & 9 \\
\hline Total & & & 1369 \\
\hline
\end{tabular}

